Original Research Article

\title{
Activity of Tulsi leaves (Ocimum sanctum linn) in protecting gastric ulcer in rats by cold restrain method
}

\author{
Ayesha Vaseem ${ }^{1 *}$, Mazher Ali², Khuteja Afshan ${ }^{1}$
}

\author{
${ }^{1}$ Department of Pharmacology, \\ ${ }^{2}$ Department of Psychiatry, \\ Deccan College of Medical \\ Sciences, Hyderabad, \\ Telangana, India
}

Received: 14 September 2017

Accepted: 19 September 2017

\section{*Correspondence to: \\ Dr. Ayesha Vaseem, \\ Email: drayeshamazher@ \\ gmail.com}

Copyright: (C) the author(s), publisher and licensee Medip Academy. This is an openaccess article distributed under the terms of the Creative Commons Attribution NonCommercial License, which permits unrestricted noncommercial use, distribution, and reproduction in any medium, provided the original work is properly cited.

\begin{abstract}
Background: Tulsi (Ocimum sanctum L.) common household plant, a potent adaptogen has been used for its medicinal property for many years. It is known in Ayurveda as Incomparable one, Mother of medicine of Nature and The Queen of Herbs. The present study evaluated the stress induced anti-ulcer effect of tulsi leaves in albino rats.

Methods: Albino rats were randomly, allocated to different experimental groups and aqueous leaf extract of Tulsi (Ocimum sanctum) is given for 7 days. Gastric ulcers were induced by cold restrain methods and results were compared with control using distilled water and standard drug Ranitidine.

Results: The Anti-ulcer effect of aqueous extract of Tulsi was significant in a dose dependent manner with cold restraint model. The percentage of ulcer protection of Tulsi leaf extract at dose $100 \mathrm{mg} / \mathrm{kg}$ is $68.85 \%$ and at dose of $200 \mathrm{mg} / \mathrm{kg}$ showed $65.66 \%$ and the standard drug Ranitidine showed $78.23 \%$ ulcer protection which is significant $(\mathrm{p}<0.05)$.

Conclusions: The study showed that when Tulsi (Ocimum sanctum) is given at dose $100-200 \mathrm{mg} / \mathrm{kg}$ for 7 days i.e., pre-treatment in rats for anti-ulcer effect, it caused a significant reduction in the ulcer scores and ulcer index when compared with control group, as evidenced by the gross appearance and histological findings of gastric mucosa in rats. There were few signs of mucosal injury and the percentage of damage was less compared to control group. Serosal surface revealed very few dilated blood vessels and petechial hemorrhages and mucosal surface had few ulcers of varying sizes.
\end{abstract}

Keywords: Cold restrain ulcers, Peptic ulcer, Tulsi

\section{INTRODUCTION}

Peptic ulcer is a chronic disease which impairs the quality of life and is associated with increased morbidity and mortality. Imbalance between the "aggressive" (acid, pepsin and $H$. pylori) and "defensive" factors (mucin, prostaglandin, bicarbonate, nitric oxide and growth factor) and presence of acid-pepsin play an important role. ${ }^{1,2}$ Peptic ulcer disease is a worldwide problem and its treatment is essential.

Stress is common and universal feature in human life now a days. Stress is involved in the pathogenesis of a variety of diseases that includes psychiatric disorders such as depression and anxiety, immunosuppression, endocrine disorders including diabetes mellitus, male impotence, cognitive dysfunction, peptic ulcer, hypertension and ulcerative colitis. ${ }^{3}$

In the cold-restraint stress model, gastric ulcer formation was mainly due to gastric hypermotility, which could lead to mucosal over friction. Hence, the gastric mucus layer is extremely important and the mucus is generally believed to contribute to a cytoprotective action. ${ }^{4}$

The large numbers of drugs in use are derived from plants because of their easily available, safety, effective and more 
important economical. ${ }^{5,6}$ The medicinal plants are rich in secondary metabolites (which are potential sources of drugs) and essential oils of therapeutic importance. Plants are the source of certain known anti-ulcer drugs. ${ }^{7}$ Tulsi has been reported in traditional medicine to possess antirheumatic, anti-stress and anti-bacterial properties. ${ }^{8}$

According to World Health Organization, medicinal plants are the best source to obtain a variety of newer herbal drugs. About $80 \%$ of individuals from developed countries use traditional medicine, has compounds derived from medicinal plants therefore, such plants should be investigated for better understanding of their properties, safety and efficacy.

\section{METHODS}

\section{Animals}

Albino rats of either sex weighing between 150-200gms were used for the study and were randomly, allocated to different experimental groups and placed individually in cages. Care being taken to avoid coprophagy, by keeping the animals in cages with grating floor. If coprophagy was detected such animals were excluded from the study. Animals were kept at room temperature and 12; 12 hours, light darkness cycle was maintained

Tulsi leaves extract (aqueous) obtained from S. J. Herbals and Health Care. Bengaluru, Karnataka, India. The extract was stored in cool and dry place. Accurately weighed quantity of extract suspended in distilled water and administered orally to rats using feeding tube.

\section{Drug}

Standard drug used is Ranitidine obtained from Saraca Laboratories Limited. It was suspended in distilled water and administered orally through feeding tube.

\section{Methods of inducing stress ulcers in rats}

\section{Cold restraint method ${ }^{9}$}

Rats were immobilized in stress cage and kept in refrigerator $\left(4-6^{\circ} \mathrm{C}\right)$ for 3 hours. The animals sacrificed by stunning method and the severity of mucosal lesions were scored as ulcer index.

Pretreatment - Rats were given Tulsi leaf extract for of 7 days. After 7 days Rats was kept fasting for $12 \mathrm{hrs}$, then subjected to stress and sacrificed by stunning method. The stomachs were opened along the greater curvature and the stomach were isolated and washed in normal saline. Those stomachs were fixed on wooden board with the help of pins. The stomachs were observed with the help of magnifying lens and studied its external and internal surface and observed hemorrhage, dilation of blood vessels, ulceration, perforation, size and number of ulcers and ulcer index was evaluated according to the severity of ulcers. The stomach was stored and fixed in 5\% formalin.

The percentage of ulcer inhibition calculated by formula

Percentage of ulcer inhibition $=$

Mean Ulcer index (Control) - Mean Ulcer index (Treated)X 100 Mean Ulcer index of control

\section{Ulcer indexing ${ }^{10}$}

The dissected-out stomachs were cut open along the greater curvature and the inner surface was examined for ulceration. The open stomachs were fixed on to a board with the help of pins and studied by individuals who were blinded for test drugs and control animals.

\section{Evaluation of ulcers}

- $\quad 0$ - No pathology

- $\quad 1$ - A small ulcer (1-2mm)

- 2-Medium ulcer (3-4mm)

- 4 - Large ulcer (5-6mm)

- 8 - Large ulcer $(>6 \mathrm{~mm})$

Total severity of scores

Ulcer index $=$

\section{Number of animals}

\section{Histological studies}

A portion of the ulcer region in the stomach was dissected out and fixed in 5\% buffered neutral formalin solution for histological observations. After fixations, tissues were embedded in paraffin, solid sections were cut at $5 \mu \mathrm{m}$ and stained with hematoxylin and eosin. The sections were examined with the help of a pathologist under light microscope and photomicrographs were taken.

\section{Statistical analysis}

Data is expressed as mean \pm SEM. Data was by one-way ANOVA followed by LSD and Scheffe's multiple comparisons test. The significance of difference was accepted at $\mathrm{P}<0.01$.

\section{RESULTS}

\section{Gross appearance of gastric mucosa in rats}

On gross examination, serosal surface of stomach showed marked induration, dilated blood vessels, ecchymosis and haemorrhagic sites. Mucosal surface presented with features of severe degree of hyperemia, congestion and large number of pin point ulcers of varying sizes with central clots, features of perforation in the stomach. The ulcer index was high. Microscopic features were 
suggestive of acute gastric ulceration with deepithelialization.

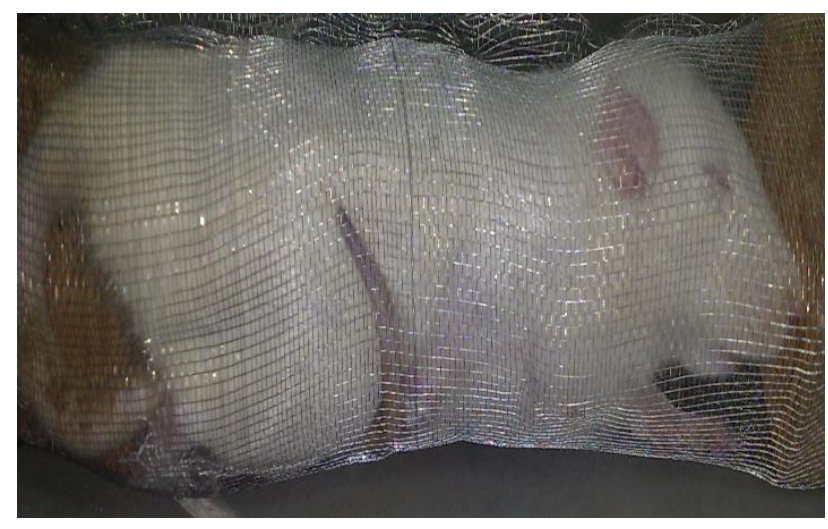

Figure 1: Restraint rat.

Table 1: Grouping of animals $(\mathrm{N}=30)$.

\begin{tabular}{|llll|}
\hline $\begin{array}{l}\text { Group } \\
(\mathbf{n = 6})\end{array}$ & Drug & $\begin{array}{l}\text { Dose } \\
(\mathbf{m g} / \mathrm{kg})\end{array}$ & Route \\
\hline I & Distilled water & $10 \mathrm{ml} / \mathrm{kg}$ & Oral \\
\hline II & Tulsi leaf extract & 50 & Oral \\
\hline III & Tulsi leaf extract & 100 & Oral \\
\hline IV & Tulsi leaf extract & 200 & Oral \\
\hline V & Ranitidine & 10 & Oral \\
\hline
\end{tabular}

Drug given once daily for 7 days

Table 2: Effect of TLE against cold restraint -induced gastric ulcers in rats $(\mathrm{N}=30)$.

\begin{tabular}{|llll|}
\hline Treatment & $\begin{array}{l}\text { Dose } \\
(\mathbf{m g} / \mathrm{kg}) \\
(\mathbf{n = 6})\end{array}$ & $\begin{array}{l}\text { Cold restraint } \\
\text { Ulcer index } \\
\text { (Mean+SD) }\end{array}$ & $\begin{array}{l}\text { \% of ulcer } \\
\text { protection }\end{array}$ \\
\hline $\begin{array}{l}\text { Distilled } \\
\text { water }\end{array}$ & $10 \mathrm{ml} / \mathrm{kg}$ & $5.33 \pm 1.86$ & - \\
\hline $\begin{array}{l}\text { Tulsi leaf } \\
\text { extract }\end{array}$ & 50 & $4.0 \pm 1.54$ & 24.95 \\
\hline $\begin{array}{l}\text { Tulsi leaf } \\
\text { extract }\end{array}$ & 100 & $1.66 \pm 0.98$ & 68.85 \\
\hline $\begin{array}{l}\text { Tulsi leaf } \\
\text { extract }\end{array}$ & 200 & $1.83 \pm 0.51$ & 65.66 \\
\hline Ranitidine & 10 & $1.16 \pm 0.75$ & 78.23 \\
\hline
\end{tabular}

Table 3: One way ANOVA for cold-restraint ulcer.

\begin{tabular}{|lllllll|}
\hline Source & SS & df & MS & F & P & Sig \\
\hline Between & 56.46 & 4 & 14.11 & 7.55 & $\begin{array}{l}\text { P } \\
<0.001\end{array}$ & $* * *$ \\
\hline Within & 35.50 & 19 & 1.87 & & & \\
\hline Total & 91.95833 & 23 & & & & \\
\hline
\end{tabular}

Tulsi leaf extract pretreated rats at the dose 100 and $200 \mathrm{mg} / \mathrm{kg}$ showed few signs of mucosal injury, but the percentage of damage was less compared to control group. Serosal surface revealed very few dilated blood vessels and peticheal haemorrhages. Mucosal surface revealed few ulcers of varying sizes. Correspondingly the ulcer index also was reduced. These features were suggestive of anti-ulcer activity of Ocimum sanctum.

Table 4: Multiple comparison tables (post-hoc test) for cold restraint ulcer.

\begin{tabular}{|c|c|c|c|}
\hline \multicolumn{4}{|c|}{ Critical value } \\
\hline$\alpha$ & LSD test & Sch & fe's test \\
\hline \multirow[t]{2}{*}{0.05} & 1.65 & 2.69 & \\
\hline & & $\begin{array}{l}\text { LSD } \\
\text { test }\end{array}$ & $\begin{array}{l}\text { Scheffe' } \\
\text { test }\end{array}$ \\
\hline C vs. R & 4.17 & $*$ & $*$ \\
\hline C vs. T.L.E 50 & 1.33 & ns & ns \\
\hline C vs. T.L.E 100 & 3.67 & $*$ & $*$ \\
\hline C vs. T.L.E 200 & 3.50 & $*$ & $*$ \\
\hline R vs. T.L.E 50 & 2.83 & $*$ & ns \\
\hline R vs. T.L.E 100 & 0.50 & ns & ns \\
\hline R vs. T.L.E 200 & 0.67 & ns & ns \\
\hline T.L.E 50 vs. T.L.E 100 & 2.33 & $*$ & ns \\
\hline T.L.E 50 vs. T.L.E 200 & 2.17 & $*$ & ns \\
\hline T.L.E 100 vs. T.L.E 200 & 0.17 & ns & ns \\
\hline
\end{tabular}

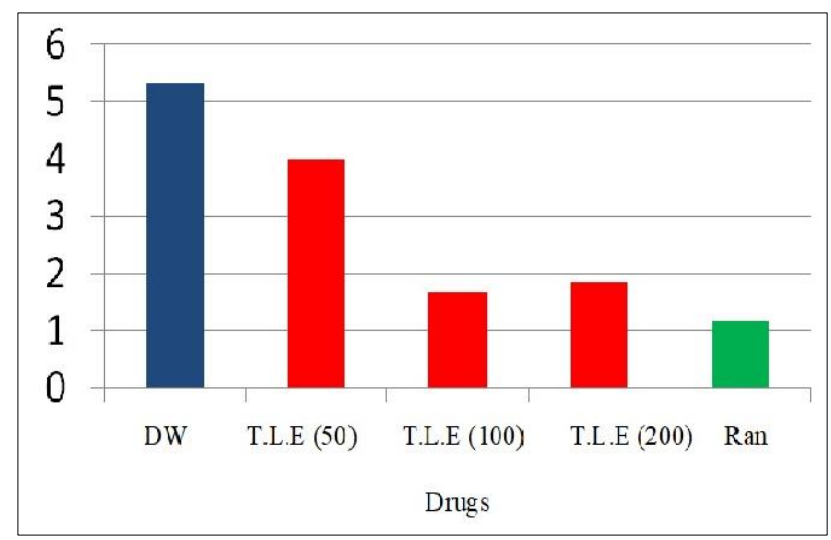

DW - Distilled water

T.L.E - Tulsi leaf extract

Ran - Ranitidine

Figure 2: Comparing ulcer index in cold restraint $\operatorname{method}(n=6)$.

Animals treated with ranitidine maintained near normal pattern. Serosal surface looked amber coloured with few signs of dilated blood vessels and haemorrhagic suffusions. Mucosal surface retained the normal rugae pattern with minimal signs of mucosal injury. The ulcer index was markedly reduced.

\section{DISCUSSION}

Many factors have been associated with peptic ulcer, most important of which is stress. Drugs available for peptic ulcers in the market were limited by presence of several adverse, hence focus has shifted towards natural products as the new sources of antiulcer agents. With the increasingly growing interest in natural medicine, various 
plants have been studied based on the traditional knowledge of their pharmacological properties and confirmed to be useful in treatment and management of various diseases including gastric and duodenal ulcer. Tulsi has been one of the most noteworthy plant mentioned in various medicinal systems. In addition to other therapeutic properties. ${ }^{3,10,11}$ Ocimum sanctum is also reported to possess anti-ulcerogenic activity. The stem and leaves of Tulsi contain a variety of phytochemical constituents that may have biological activity, including saponins, flavonoids, triterpenoids, and tannins. ${ }^{12-14}$ In addition, the following phenolic actives - Rosmarinic acid, apigenin, cirsimaritin, isothymusin and isothymonin have been identified, which also exhibit antioxidant and antiinflammatory activities.

The present study is undertaken to produce gastric ulcers by cold restrain models in albino rats. It is a well-accepted model for the induction of gastric ulcer and provide both emotional stress as well as physiological stress to the animal. ${ }^{15}$ The percentage of ulcer protection of Tulsi leaf extract $100 \mathrm{mg} / \mathrm{kg}$ and $200 \mathrm{mg} / \mathrm{kg}$ and standard drug ranitidine were almost comparable. Therefore, the results were suggestive of anti ulcerogenic activity of Ocimum sanctum at the dose $100-200 \mathrm{mg} / \mathrm{kg}$.

Tulsi has been reported to possess adaptogenic activity, its anti-ulcerogenic effect may be due to its effect on neural pathways controlling acid secretion thereby strengthening the animal's physiological capabilities to decrease stress and hence ulcers. ${ }^{16,17}$

Accordingly, the protective action of Tulsi against stressinduced ulceration could be due to its histamine antagonistic, anticholinergic and antisecretory effects.

However, further study is required to know the exact mechanism of action and to isolate the active molecule responsible for the anti-ulcer activity.

\section{CONCLUSION}

The finding of the present study demonstrated that Tulsi leaf extract (Ocimum sanctum) at dose of $100 \mathrm{mg} / \mathrm{kg}$ showed $68.85 \%$ ulcer protection and at dose of $200 \mathrm{mg} / \mathrm{kg}$ showed $65.66 \%$ ulcer protection which is significant ( $p$ $<0.05$ ) anti-ulcer effect in Cold restraint stress method and the standard drug Ranitidine, a $\mathrm{H}_{2}$ receptor antagonist commonly prescribed in stress ulcers has shown more potent $78.23 \%$ in comparison to Tulsi against cold restraint ulcer, as evidenced by decrease in number and severity of the ulcer and the reduction in the ulcer scores.. However more experimentation and clinical studies and detailed analysis are required for a definitive conclusion.

\section{Funding: No funding sources} Conflict of interest: None declared

Ethical approval: The study was approved by the Institutional Animal Ethics Committee

\section{REFERENCES}

1. Hoogerwerf WA, Pasricha PJ. Agents used for control of gastric acidity and treatment of peptic ulcers and gastroesophageal reflux disease. In: Hardman JG, Limbird LE, Goodman Gilaman A, editors. Goodman and Gilman the Pharmacological Basis of Therapeutics. 10 ${ }^{\text {th }}$ Ed. New York: Mc Graw-Hill; 2001:1005-1019.

2. Falcao HS, Mariath IR, Diniz MFFM, Batista LM, Barbosa JM. Filho, Phytomed. 2008;15:132-46.

3. Bijlani RL, Vempati RP, Yadav RK, Ray RB, Gupta $\mathrm{V}$, Sharma R, et al. A brief but comprehensive lifestyle education program based on yoga reduces risk factors for cardiovascular disease and diabetes mellitus. Journal of Alternative \& Complementary Medicine. 2005 Apr 1;11(2):267-74.

4. Qiu BS, Cho CH, Ogle CW. The influence of chronic nicotine treatment on stress-induced gastric ulceration and emptying rate in rats. Experientia. 1992;48:38991.

5. Perry MA, Wadhwa S, Parks DA, Pickard W, Granger DN. Role of oxygen radicals in ischemia-induced lesions in the cat stomach. Gastroenterology. $1986 \mathrm{Feb}$ 28;90(2):362-7.

6. Jana U, Bhattacharyya D, Bandopadhyay S, Pandit S, Debnath PK, Sur TK. Antiulcer activity of digitrall: A polyherbal drug in rats. 2005;37:406-7.

7. Pihan G, Regillo C, Szabo S. Free radicals and lipid peroxidation in ethanol and aspirin-induced gastric mucosal injury. Dig Dis Sci. 1987;32:1395-401.

8. Atal CK, Kapoor BM. Cultivation and utilization of medicinal plants (Eds. PID CSIR), 1989.

9. Vincent G, Glavin G, Rutkowski J, Pare W. Body orientation, food deprivation and potentiation of restraint induced gastric lesions. Gastroenterologie clinique et biologique. 1977;1(6-7):539.

10. Nagaraja HS, Jeganathan PS. Forced Swimming stress induced alterations in ingestive behavior in rats. Indain journal of Physiology Pharmacology. 2003;41(1):94100.

11. Sahakari SD, Abraham ME, Mascarenhas JF. Effect of stress on maternal behaviour. Indian journal of physiology and pharmacology. 1989 Apr 1;33(2):936.

12. Kelm MA, Nair MG, Strasburg GM, DeWitt DL. Antioxidant and cyclooxygenase inhibitory phenolic compounds from Ocimum sanctum Linn. Phytomedicine. 2000;7:7-13.

13. Shishodia S, Majumdar S, Banerjee S, Aggarwal BB. Urosolic acidinhibits nuclear factor-kappaB activation induced by carcinogenic agents through suppression of IkappaBalpha kinase and p65 phosphorylation: Correlation with down-regulation of cyclooxygenase 2, matrix metalloproteinase 9 , and cyclin D1. Cancer Res. 2003;63:4375-83.

14. Jaggi RK, Madaan R, Singh B. Anticonvulsant potential of holy basil, Ocimum sanctum Linn., and its cultures. Indian J Exp Biol. 2003;41;1329-33. 
15. Dharmani P, Kuchibhotla VK, Maurya R, Srivastava S, Sharma S, Patil G. Evaluation of anti-ulcerogenic and ulcer-healing properties of Ocimum sanctum Linn. J Ethnophamacol. 2004;93:197-206.

16. Pandey G, Madhuri S. Pharmacological activities of Ocimum sanctum (tulsi): a review. Int J Pharm Sci Rev Res. 2010;5:61-6.
17. Cohen MM. Tulsi - Ocimum sanctum: A herb for all reasons. Journal of Ayurveda and Integrative Medicine. 2014;5(4):251-9.

Cite this article as: Vaseem A, Mazher A, Khuteja A. Activity of Tulsi leaves (Ocimum sanctum linn) in protecting gastric ulcer in rats by cold restrain method. Int J Basic Clin Pharmacol 2017;6:2343-7. 